\title{
Daikon Radish Cultivation Guide for Florida ${ }^{1}$
}

\author{
Mary Dixon and Guodong Liu²
}

\section{General Description}

Daikon (meaning "big root" in Japanese) radish (Raphanus sativus L., Longipinnatus group), originally native to East Asia (Larkcom and Douglas 1994), is a versatile vegetable crop in the mustard family, Brassicaceae (formerly Cruciferae) (Weil et al. 2009). Brassicaceae species are herbaceous, and most are aromatic. The typically small flowers have four petals and four sepals arranged in an indicative cross shape (Figure 1). Brassicaceae has many members commercially grown as ornamentals (Iberis, Lunaria, Nasturtium) and food crops (mostly Brassica species).



Figure 1. Daikon radish flowers. These images show the whole inflorescence (A), a close-up of the flowers (B), and a visiting pollinator (C).

Credits: Mary Dixon, UF/IFAS
Daikon radish produces a large, white, cylindrical fleshy root that protrudes several inches above the soil and can weigh 10-20 lb in Florida soil (Stephens 1994). Commercially grown daikon radishes are typically harvested at $12-14$ inches in length for the processing market and 2.5 inches for the Asian vegetable market (Molinar et al. 2005).

Daikon radish likely has multiple origins from wild radish species (Yamagashi 2003). The seedling develops two B-shaped cotyledons, then true leaves that are hairy and tooth-edged (MacKenzie 2018) (Figure 2). Daikon radish is an especially common vegetable in Asia, particularly in Japan (MacKenzie 2018; Tsuji 1980). Other names for daikon radish include dichon radish, forage radish, Chinese radish, Japanese radish, Oriental radish (Weil et al. 2009), white radish, winter radish, long white radish, and true daikon (Thomas 1987). This root tends to be less spicy than other garden types of radish.

\section{Propagation}

Daikon radish seeds are moderate in size, hard, and brown (Figure 3). There are no published UF/IFAS recommendations for commercial production of daikon radish in Florida. Culture is quite similar to that of the common radish (R. sativus) with the exception of plant spacing, which should be 4-6 inches in rows spaced $3 \mathrm{ft}$ apart (Stephens 1994). Daikon radish cultivars include but are not limited to 'Icicle Short Top', 'Alpine', 'Miyashige,' 'April Cross', and 'Minowase Summer Cross'. Cultivars with good

1. This document is HS1370, one of a series of the Horticultural Sciences Department, UF/IFAS Extension. Original publication date September 2020. Visit the EDIS website at https://edis.ifas.ufl.edu for the currently supported version of this publication.

2. Mary Dixon, graduate student, and Guodong Liu, associate professor, Horticultural Sciences Department; UF/IFAS Extension, Gainesville, FL 32611.

Use pesticides safely. Read and follow directions on the manufacturer's label.

The Institute of Food and Agricultural Sciences (IFAS) is an Equal Opportunity Institution authorized to provide research, educational information and other services

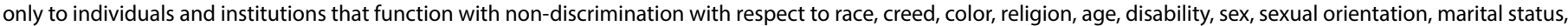

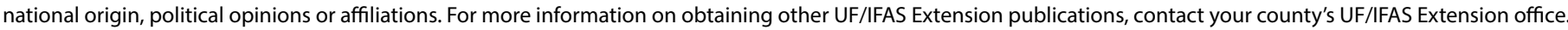
U.S. Department of Agriculture, UF/IFAS Extension Service, University of Florida, IFAS, Florida A \& M University Cooperative Extension Program, and Boards of County Commissioners Cooperating. Nick T. Place, dean for UF/IFAS Extension. 
heat tolerance and those slow to bolt are recommended for production in south Florida.

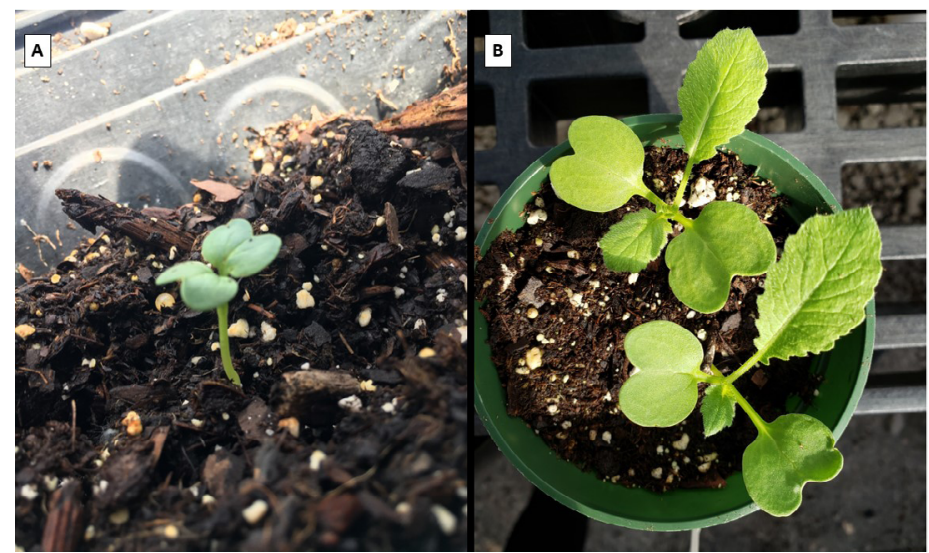

Figure 2. Daikon radish B-shaped cotyledons (A) and cotyledons with expanding true leaves (B).

Credits: Mary Dixon, UF/IFAS

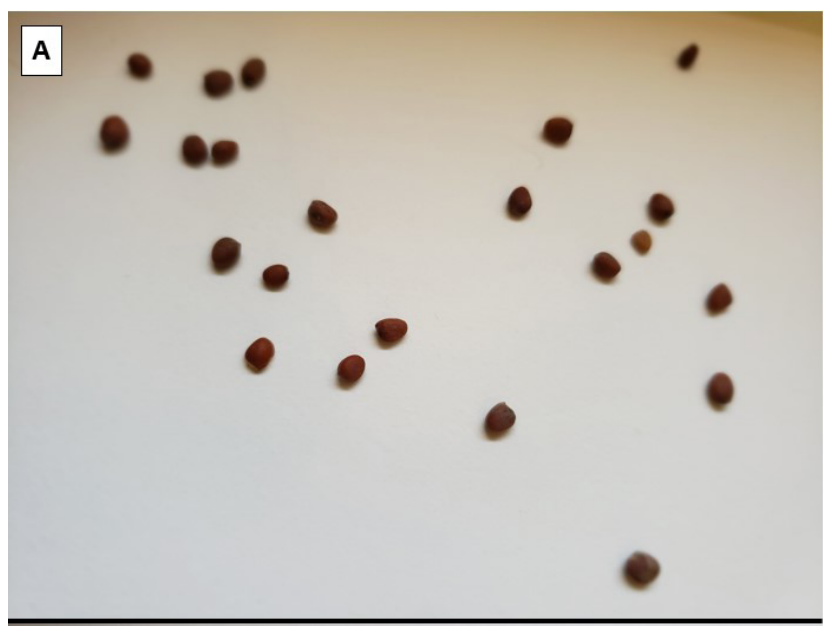

B

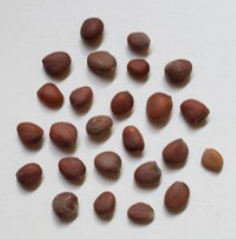

Figure 3. Daikon radish seeds (A) and with a quarter for scale (B). Credits: Mary Dixon, UF/IFAS

Recommended planting dates for radish are September to March in north Florida and October to March in central and south Florida. Sow to a depth of 0.5-1 inch at a rate of $1 \mathrm{lb}$ seed per acre. Daikon radish takes approximately 50-60 days to mature from seed (Dittmar et al. 2019) depending on the variety and time of year planted. Harvest daikon radish approximately 7 weeks after seeding in spring and 10 weeks in fall. Avoid allowing the crop to become overly mature, because it will become increasingly fibrous with intensified flavor if left in the ground too long (MacKenzie 2018).
Daikon radish readily germinates and grows rapidly (Weil et al. 2009), but excessive irrigation or heavy rainfall may crust the soil, weakening seedling emergence (MacKenzie 2018). Root crops benefit from having the soil loosened before planting to help facilitate root development through the soil.

\section{Growing Conditions}

Ideally, daikon radish will produce a healthy primary taproot, minimal lateral roots, and dense foliage (Figure 4) and a 20-inch-long taproot (Figure 5). Because nitrogen has been shown to stimulate lateral root branching, it is not recommended to use fresh manure, which is high in $\mathrm{N}$, with daikon radish (MacKenzie 2018). Root length and fresh weight have been shown to increase when supplied with $50 \%$ vermicompost and $50 \%$ poultry manure (Kumar et al. 2014).

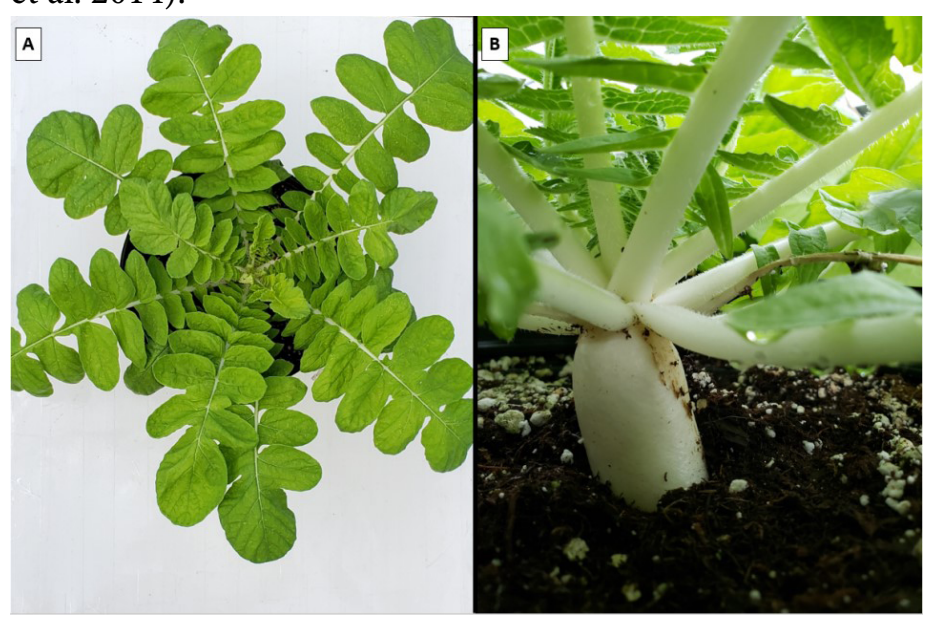

Figure 4. Healthy daikon radish foliage (A) and root (B) at approximately 6 weeks.

Credits: Mary Dixon, UF/IFAS

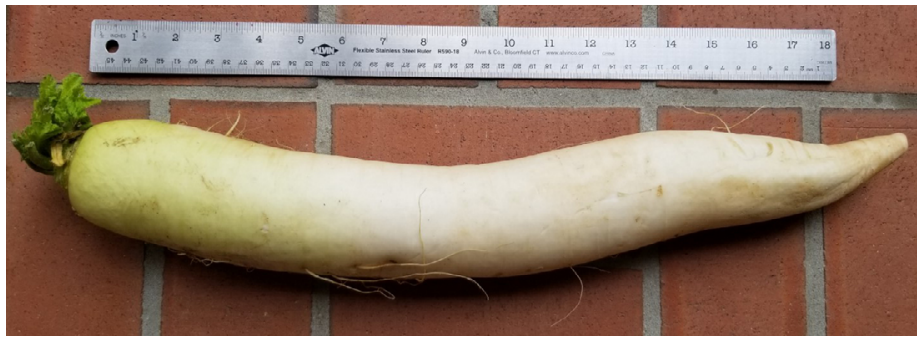

Figure 5. An approximately 20-inch-long fresh daikon radish produce collected from a Chinese grocery in Gainesville, FL on May 26, 2020.

Credits: Guodong Liu, UF/IFAS

Optimal soil $\mathrm{pH}$ for daikon radish is slightly acidic to neutral (pH 6-7) (MacKenzie 2018). Daikon radish is a cold-tolerant crop up to $25^{\circ} \mathrm{F}\left(-4^{\circ} \mathrm{C}\right)$ (MacKenzie 2018; Weil et al. 2009) with optimal temperature being between $50^{\circ} \mathrm{F}-65^{\circ} \mathrm{F}\left(10^{\circ} \mathrm{C}-18^{\circ} \mathrm{C}\right)$ (Guan 2017). This crop is neither tolerant of drought nor flooded field conditions. A water deficit may cause roots to develop poor flavor and a rough texture, and excess water will cause rot (Weil et al. 2009). 
There are no crop-specific UF/IFAS fertilizer recommendations for daikon radish available to growers at the time of this publication. For the time being, growers may use 90 $\mathrm{lb} /$ acre nitrogen, $100-120 \mathrm{lb} / \mathrm{acre}$ phosphorus pentoxide $\left(\mathrm{P}_{2} \mathrm{O}_{5}\right)$, and $80 \mathrm{lb} /$ acre for potassium oxide $\left(\mathrm{K}_{2} \mathrm{O}\right)$, based on the UF/IFAS recommendations for radish production in Florida (Liu et al. 2019).

\section{Pests and Disease}

Daikon radish is host to numerous pests. Therefore, an integrated pest management approach is necessary to reduce damage to the crop. Consider biological, cultural, mechanical, and chemical (pesticide) strategies. For chemical control recommendations, please see Chapter 15. Root Crop Production in Florida in the Vegetable Production Handbook of Florida (available at https://edis.ifas.ufl.edu/ cv300). This chapter discusses control for traditional radish, so although techniques for control may be similar to daikon radish, please make sure that the label of the herbicide, insecticide, or fungicide is approved for daikon radish use before application. Weeds are typically not a major problem for daikon radish production due to the crop's rapid growth and dense foliage. For management of weeds, it is recommended to mulch and shallowly cultivate so as not to damage the roots (MacKenzie 2018).

Daikon radish is host to many insects, including mustard sawfly (Athalia lugens), an insect that feeds on young leaves and shoots. Summer plowing may help destroy the pupa, and application of bitter melon (Momordica charantia L.) seed oil emulsion or methanol leaf extract may help prevent feeding (Selvakumar et al. 2019; Yasui et al. 1998). Daikon radish is also susceptible to damage from whiteflies (Aleyrodidae) (Figure 6), which damage the crop not only by feeding on the phloem, but also by vectoring disease; whiteflies vector over 100 virus species, mostly belonging to the Begomovirus genus (90\%) (Jones 2003). Inundative release of predaceous fungus gnats (Mycetophilidae) or use of sticky traps with lime green $(530 \mathrm{~nm})$ light-emitting diodes (LEDs) may help control whitefly populations (Chu et al. 2008; Daly et al. 1998).

In addition to whitefly-vectored viral diseases, daikon radish is also susceptible to aphid-vectored viral diseases such as mosaic virus, which causes mottling of young leaves with interveinal chlorosis, resulting in reduced chlorophyll content, photosynthetic rates, transpiration rates, stomatal conductance, ribulose-1,5-bisphosphate carboxylase (RuBPCase) enzyme activity, and biomass (Guo et al. 2005; Selvakumar et al. 2019). To minimize spread of disease, immediately remove infected plants and maintain clean growing areas (Selvakumar et al. 2019). Bacterial diseases such as root rot (Erwinia rhapontici) commonly occur in daikon radish. This disease causes deterioration of pith tissue, cavity formation, and wilting. Because this disease may spread through the irrigation, it is recommended to ensure clean water is used to supply crops (Selvakumar et al. 2019). Irrigation may also impact the occurrence of radish scab (Streptomyces), which causes unmarketable circular lesions on the hypocotyl and root. It was found that irrigating at consistent 2-to-3-day intervals reduces the occurrence of radish scab (Levick et al. 1985).

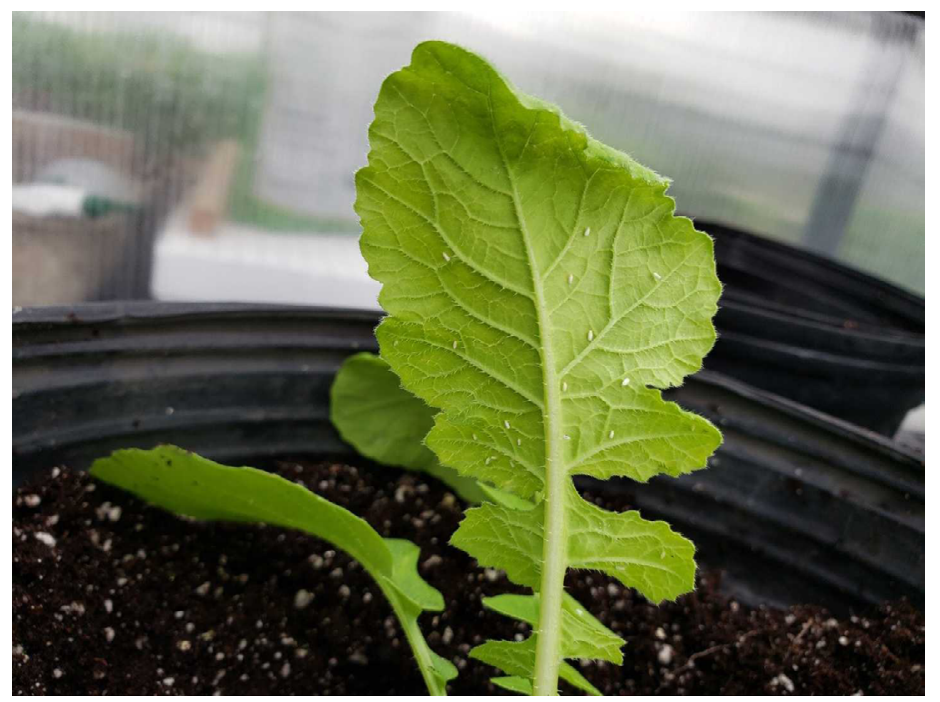

Figure 6. Whiteflies on a daikon radish host. Credits: Mary Dixon, UF/IFAS

\section{Agricultural, Culinary, and Medicinal Uses}

Daikon radish may control Plasmodiophora brassicae, which causes clubroot disease in many Brassicaceae members by acting as a decoy crop to stimulate germination of resting spores. Murakami et al. (2001) found that this disease infected daikon radish root hairs, but did not form clubs, and ultimately reduced the incidence of club formation when planted in advance of more susceptible crops, such as Chinese cabbage (Brassica rapa). Daikon radish can also be used as a fall and winter cover crop. Cover crops are beneficial for reducing nitrate leaching, enhancing soil organic matter, controlling soil erosion, and cycling soil phosphate to enhance lability and availability (Soltangheisi et al. 2018; Weil et al. 2009). It makes for a quality cover crop because the residues release mineral nutrients rapidly and it decomposes quickly, provided it does not become overly mature. Certain cultivars of daikon radish may help mitigate the effects of soil compaction through the activity of their deep penetrating roots into dense soil. When the roots decompose, root channels are left behind, allowing improved water percolation through 
compacted soil. Additionally, early-cultivated daikon radish may establish a stand of dense foliage, which helps manage weeds and reduces contributions of additional weed seed to the seedbed.

While there are clear agricultural uses for daikon radish, it is primarily grown for culinary purposes, because of the flavorful and nutritious root. Daikon radish is a vegetable that promotes a healthy lifestyle, with high amounts of vitamins ( $\mathrm{B}_{6}$ and $\mathrm{C}$ ) and minerals (manganese, potassium, and phosphorus) (USDA FDC 2019). It is popular in Southeast Asian cuisines due to its mild flavor and high concentrations of beneficial glucosinolates (Weil et al. 2009), which occur as secondary metabolites of almost all members of the order Brassicales. These natural components of many pungent species, such as daikon radish, contribute to plant defense against diseases and pests. The nutrient-rich root is typically harvested, washed, and eaten raw in salads (Table 1). The root may also be pickled, steamed, or sliced to cook for a wide variety of dishes, typically by simmering in thick sauces (Tsuji 2007). Daikon radish greens are also edible and nutritious. Usually, the greens are sautéed or lightly stir-fried (Borgman 2018). It is recommended to immediately remove them from the root and store in the refrigerator for up to three days, though some markets prefer the leaves to remain attached to the root. For long-term storage up to 4 months, it is recommended to store daikon radish between $32^{\circ} \mathrm{F}-34^{\circ} \mathrm{F}$ at $95 \%-100 \%$ relative humidity (Maynard and Hochmuth 2007).

Medicinal properties have been noted in daikon radish, largely from its high concentration of glucosinolates relative to other vegetables and to other radishes (200-399 $\mu \mathrm{mol} / 100 \mathrm{~g}$ ) (Carlson et al. 1985). Glucosinolates are healthy secondary plant compounds that have potent anticarcinogenic effects by inhibiting carcinogenesis; antibacterial effects to intestinal disease-causing bacteria, including Bacillus cereus and Staphylococcus aureus; antioxidant effects by regulating xenobiotic metabolizing enzymes that induce long-lasting antioxidant activity; and antimutagenic effects by decreasing mutagen activity (Vig et al. 2009). Daikon radish possesses cytosolic myrosinase, an enzyme that also demonstrates antimicrobial, antimutagenic, and anticarcinogenic activity (Nakamura et al. 2008).

\section{References}

Borgman, M. 2018. "Radish variety can add flavor and crunch to your meals." Michigan State University Extension. Accessed May 18, 2020. https://www.canr.msu.edu/news/ radish_variety_can_add_flavor_and_crunch_to_your_ meals
Carlson, D. G., M. E. Daxenbichler, C. H. VanEtten, C. B. Hill, and P. H. Williams. 1985. "Glucosinolates in Radish Cultivars." Journal of the American Society for Horticultural Science 110 (5): 634.

Chu, C.-C., A. M. Simmons, T.-Y. Chen, P. J. Alexander, and T. J. Henneberry. 2008. "Lime Green Light Emitting Diode Equipped Yellow Sticky Card Traps for Monitoring Whiteflies, Aphids and Fungus Gnats in Greenhouses." Insect Science 11 (2): 125-133.

Daly, H. V., J. T. Doyen, and A. H. Purcell III. 1998. "Ch. 14 Pest management." In Introduction to Insect Biology and Diversity. New York: Oxford University Press.

Dittmar, P. J., E. J. McAvoy, M. Ozores-Hampton, R. N. Raid, H. A. Smith, S. E. Webb, L. Zotarelli, S. Zhang, C. F. Miller, and Q. Wang. 2019. Chapter 15: Root Crop Production in Florida. In Vegetable Production Handbook of Florida, 2019-2020 edition. HS965. Gainesville: University of Florida Institute of Food and Agricultural Sciences. https://edis.ifas.ufl.edu/cv300

Guan, W. 2017. "Daikon Radish.” Purdue University Extension Vegetable Crops Hotline.

Guo, Y. P., D. P. Guo, Y. Peng, and J. S. Chen. 2005.

"Photosynthetic Responses of Radish (Raphanus saticus var. longipinnatus) Plants to Infection by Turnip Mosaic Virus." Photosynthetica 43 (3): 457-462.

Jones, D. R. 2003. "Plant Viruses Transmitted by Whiteflies." European Journal of Plant Pathology 109:195-219.

Kumar, S., S. Maji, S. Kumar, and H. D. Singh. 2014. "Efficacy of Organic Manures on Growth and Yield of Radish (Raphanus sativus L.) cv. Japanese White." International Journal of Plant Sciences (Muzaffarnagar) 9 (1): 57-60.

Larkcom, J., and E. Douglass. 1994. Oriental Vegetables: The Complete Guide for the Gardening Cook. New York: Oxford University Press US. pp. 114-115.

Levick, D. R., T. A. Evans, C. T. Stephens, and M. L. Lacy. 1985. "Etiology of Radish Scab and Its Control through Irrigation." The American Phytopathological Society 75 (5): $568-572$.

Liu, G., E. H. Simonne, K. T. Morgan, G. J. Hochmuth, S. Agehara, and R. Mylavarapu. 2019. "Chapter 2. Fertilizer Management for Vegetable Production in Florida." In Vegetable Production Handbook of Florida 2019-2020 
edition. HS296. Gainesville: University of Florida Institute of Food and Agricultural Sciences. https://edis.ifas.ufl.edu/ cv296

Maynard, D. M., and G. J. Hochmuth. 2007. "Part 8 - Harvesting, Handling, and Storage." In Knott's Handbook for Vegetable Growers. 401-502. Hoboken, NJ: John Wiley and Sons.

Molinar, R. H., M. Yang, K. M. Klonsky, and R. L. De Moura. 2005. Sample Costs to Produce Daikon (Oriental Radish). DR-VS-05. University of California Cooperative Extension. Accessed May 18, 2020. https://coststudyfiles. ucdavis.edu/uploads/cs_public/d8/a3/d8a3d951-32514142-9fad-55e505e04c07/daikonvs2005.pdf

Multilingual Multiscript Plant Name Database. 1995. Raphanus sativus L. (Longipinnatus Group). Accessed May 18, 2020. http://www.plantnames.unimelb.edu.au/new/ Raphanus.html\#longipinnatus

Murakami, H., S. Tsushima, T. Akimoto, K. Murakami, I. Goto, and Y. Shishido. 2001. "Effects of Growing Leafy Daikon (Raphanus sativus) on Populations of Plasmodiophora brassicae (Clubroot)." Plant Pathology 49:584-589.

Nakamura, Y., K. Nakamura, Y. Asai, T. Wada, K. Tanaka, T. Matsuo, S. Okamoto, J. Meijer, Y. Kitamura, A. Nishikawa, E. Y. Park, K. Sato, and K. Ohtsuki. 2008. "Comparison of the Glucosinolate-Myrosinase Systems among Daikon (Raphanus sativus, Japanese White Radish) Varieties." Journal of Agricultural and Food Chemistry 56 (8): 2702-2707.

Soltangheisi, A., M. Rodrigues, M. J. A. Coelho, A. M. Gasperini, L. R. Sartor, and P. S. Pavinato. 2018. "Changes in Soil Phosphorus Lability Promoted by Phosphate Sources and Cover Crops." Soil and Tillage Research 179:20-28.

Stephens, J. M. 1994. Radish, Chinese-Raphanus sativus $L$. HS653. Gainesville: University of Florida Institute of Food and Agricultural Sciences. https://edis.ifas.ufl.edu/mv120

Thomas, R. B. 1987. The Old Farmer's Almanac. Dublin, $\mathrm{NH}$ : Yankee Publishing Incorporated.

Tsuji, S. 1980. Japanese Cooking: A Simple Art. Tokyo: Kodansha International.

USDA Food Data Central. 2019. "Radishes, Oriental, Raw.” USDA Agricultural Research Service. Accessed May 18, 2020. https://fdc.nal.usda.gov/fdc-app.html\#/ food-details/168451/nutrients
Vig, A. P., G. Rampal, T. S. Thind, and S. Arora. 2009. "Bioprotective Effects of Glucosinolates: A Review." $L W T$ - Food Science and Technology 42:1561-1572.

Weil, R., C. White, and Y. Lawley. 2009. Forage Radish: New Multi-purpose Cover Crop for the Mid-Atlantic. Fact Sheet \#824. College Park, MD: University of Maryland Extension.

Yasui, H., A. Kato, and M. Yazawa. 1998. "Antifeedants to Armyworms, Spodoptera litura and Pseudaletia separate, from Bitter Gourd Leaves, Momordica charantia." Journal of Chemical Ecology 24:803-813. 
Table 1. Proximate composition and nutrient composition of raw daikon radish roots. Data pulled from USDA FDC, National Nutrient Database, available at https://fdc.nal.usda.gov/fdc-app.html\#/food-details/168451/nutrients.

Nutrient

Unit

$100 \mathrm{~g}$

1 cup slice $(116 \mathrm{~g}) \quad 1$ radish $\left(7^{\prime \prime}\right.$ long, $338 \mathrm{~g})$

\section{Proximates}

Water

Energy

\begin{tabular}{|c|c|}
\hline $\mathrm{g}$ & 94.7 \\
\hline $\mathrm{kcal}$ & 18.0 \\
\hline $\mathrm{g}$ & 0.6 \\
\hline $\mathrm{g}$ & 0.1 \\
\hline $\mathrm{g}$ & 0.6 \\
\hline $\mathrm{g}$ & 4.1 \\
\hline $\mathrm{g}$ & 1.6 \\
\hline $\mathrm{g}$ & 2.5 \\
\hline
\end{tabular}

\begin{tabular}{|c|c|c|}
\hline 94.7 & 109.8 & 320 \\
\hline 18.0 & 20.9 & 60.8 \\
\hline 0.6 & 0.7 & 2.03 \\
\hline 0.1 & 0.1 & 0.338 \\
\hline 0.6 & 0.7 & 1.96 \\
\hline 4.1 & 4.8 & 13.9 \\
\hline 1.6 & 1.9 & 5.41 \\
\hline 2.5 & 2.9 & 8.45 \\
\hline
\end{tabular}

\section{Minerals}

\section{Calcium, Ca}

Iron, $\mathrm{Fe}$

Magnesium, Mg

Phosphorus, $\mathrm{P}$

Potassium, $\mathrm{K}$

Sodium, $\mathrm{Na}$

Zinc, Zn

Copper, $\mathrm{Cu}$

Manganese, $\mathrm{Mn}$

Selenium, Se

\section{Vitamins}

Vitamin C, total ascorbic acid

Thiamin

Riboflavin

Niacin

Pantothenic acid

Vitamin B-6

Folate, total

Folate, food

Folate, DFE

Choline, total

Betaine

Vitamin K (phylloquinone)

\section{Lipids}

Fatty acids, total saturated

Fatty acids, total monounsaturated

Fatty acids, total polyunsaturated

\section{Amino Acids}

Tryptophan

Threonine

Isoleucine

Leucine

Lysine

\begin{tabular}{|c|c|c|c|}
\hline $\mathrm{mg}$ & 27.0 & 31.3 & 91.3 \\
\hline $\mathrm{mg}$ & 0.4 & 0.5 & 1.35 \\
\hline $\mathrm{mg}$ & 16.0 & 18.6 & 54.1 \\
\hline $\mathrm{mg}$ & 23.0 & 26.7 & 77.7 \\
\hline $\mathrm{mg}$ & 226.9 & 263.2 & 767 \\
\hline $\mathrm{mg}$ & 21.0 & 24.4 & 71 \\
\hline $\mathrm{mg}$ & 0.2 & 0.2 & 0.507 \\
\hline $\mathrm{mg}$ & 0.1 & 0.1 & 0.389 \\
\hline $\mathrm{mg}$ & 0.0 & 0.0 & 0.128 \\
\hline$\mu g$ & 0.7 & 0.8 & 2.37 \\
\hline
\end{tabular}

\begin{tabular}{c|c|c|c|}
\hline $\mathrm{mg}$ & 22.0 & 25.5 & 74.4 \\
\hline $\mathrm{mg}$ & 0.0 & 0.0 & 0.068 \\
\hline $\mathrm{mg}$ & 0.0 & 0.0 & 0.068 \\
\hline $\mathrm{mg}$ & 0.2 & 0.2 & 0.676 \\
\hline $\mathrm{mg}$ & 0.1 & 0.2 & 0.466 \\
\hline $\mathrm{mg}$ & 0.0 & 0.1 & 0.155 \\
\hline$\mu \mathrm{g}$ & 28.0 & 32.5 & 94.6 \\
\hline$\mu \mathrm{g}$ & 28.0 & 32.5 & 94.6 \\
\hline$\mu \mathrm{g}$ & 28.0 & 32.5 & 94.6 \\
\hline $\mathrm{mg}$ & 7.3 & 8.5 & 24.7 \\
\hline $\mathrm{mg}$ & 0.1 & 0.1 & 0.338 \\
\hline$\mu \mathrm{gg}$ & 0.3 & 0.3 & 1.01 \\
\hline
\end{tabular}

\begin{tabular}{c|c|c|c|}
\hline $\mathrm{mg}$ & 29.9 & 34.7 & 101 \\
\hline $\mathrm{mg}$ & 16.9 & 19.6 & 57 \\
\hline $\mathrm{mg}$ & 45.0 & 52.2 & 152 \\
\hline
\end{tabular}

\begin{tabular}{|l|c|c|c|}
\hline $\mathrm{mg}$ & 3.0 & 3.4 & 10 \\
\hline $\mathrm{mg}$ & 24.9 & 28.8 & 84 \\
\hline $\mathrm{mg}$ & 26.0 & 30.2 & 88 \\
\hline $\mathrm{mg}$ & 31.1 & 36.0 & 105 \\
\hline $\mathrm{mg}$ & 29.9 & 34.7 & 101 \\
\hline
\end{tabular}




\begin{tabular}{|c|c|c|c|c|}
\hline Nutrient & Unit & $100 \mathrm{~g}$ & 1 cup slice (116 g) & $\begin{array}{c}1 \text { radish (7" long } \\
338 \mathrm{~g})\end{array}$ \\
\hline Methionine & $\mathrm{mg}$ & 5.9 & 6.9 & 20 \\
\hline Cystine & $\mathrm{mg}$ & 5.0 & 5.8 & 17 \\
\hline Phenylalanine & $\mathrm{mg}$ & 20.1 & 23.3 & 68 \\
\hline Tyrosine & $\mathrm{mg}$ & 10.9 & 12.7 & 37 \\
\hline Valine & $\mathrm{mg}$ & 28.1 & 32.6 & 95 \\
\hline Arginine & $\mathrm{mg}$ & 34.9 & 40.5 & 118 \\
\hline Histidine & $\mathrm{mg}$ & 10.9 & 12.7 & 37 \\
\hline Alanine & $\mathrm{mg}$ & 18.9 & 22.0 & 64 \\
\hline Aspartic acid & $\mathrm{mg}$ & 41.1 & 47.7 & 139 \\
\hline Glutamic acid & $\mathrm{mg}$ & 113.0 & 131.1 & 382 \\
\hline Glycine & $\mathrm{mg}$ & 18.9 & 22.0 & 64 \\
\hline Proline & $\mathrm{mg}$ & 15.1 & 17.5 & 51 \\
\hline Serine & $\mathrm{mg}$ & 18.0 & 20.9 & 61 \\
\hline
\end{tabular}

